\title{
Design and Simulation of PID Controller based Pressurized Head Box in Paper Machine
}

\author{
N. Divya, S. Manoharan
}

\begin{abstract}
The head box in a paper machine is a critical component. Head box control is required for quality paper formation. Stock level and Total pressure in the paper machine head box determines the quality of the paper. This paper determines the design of PID controller for the pressure type head box. The stock level and pressure are the parameters taken into consideration.
\end{abstract}

Keywords: Head box, Paper machine, PID controller, Pressure and Stock head.

\section{INTRODUCTION}

The production of Paper and pulp is increasing despite the growth of Information technology. Paper plays a major role in day-today life. Paper production sector is one of the high demand sectors in Industrial production. First paper was invented in China [1]. Many research and developmental process have been concentrated for the improvement of paper quality. The quality of the paper depends on the paper machine process which has many sub processes. One of the most crucial process involves the control of stock and pressure in head box. The head box distributes the pulp evenly to the wire section.

Control of head box is essential for the production of quality paper [2]. This paper involves an air cushion pressurized head box for designing a controller [3]. The paper machine head box is represented in Figure.1. The goal of this paper to design a PID Controller based pressurized head box.

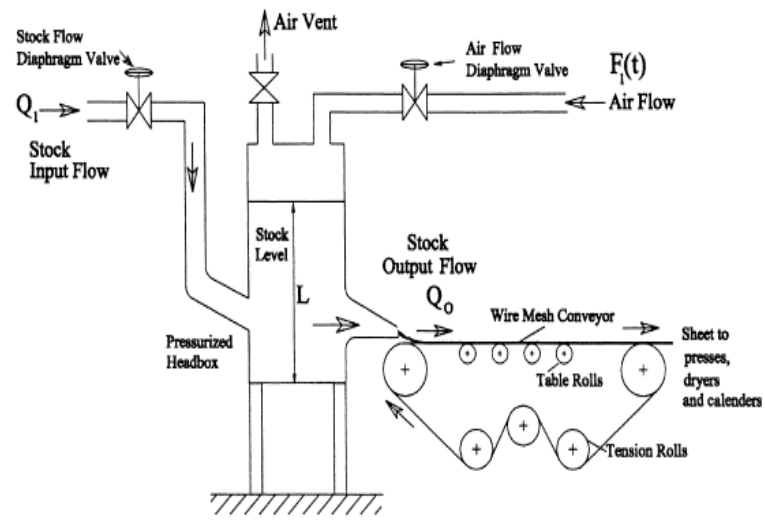

Fig. 1 Paper machine Head box [4]

Revised Manuscript Received on December 12, 2019.

N. Divya, Assistant Professor, Department of EEE, Sri Ramakrishna Engineering College, Coimbatore

S. Manoharan, Professor and Head, Department of EIE, Karpagam College of Engineering, Coimbatore

\section{MODELLING OF HEADBOX}

The head box model is considered from $[4,6]$ as follows:

$\left[\begin{array}{l}y_{1}(s) \\ y_{2}(s)\end{array}\right]=\left[\begin{array}{cc}\frac{0.528 e^{(-0.6 s)}}{(2.2 s+1)} & \frac{(1.2539 s+.063}{\left(30.051 s^{2}+17.79 s+1\right)} \\ \frac{(0.0205 s+.000149) e^{(-1.5 s)}}{\left(43.6 s^{2}+s\right)} & -\frac{(0.0007) e^{(-2 s)}}{s}\end{array}\right]\left[\begin{array}{l}u_{1}(s) \\ u_{2}(s)\end{array}\right] \quad---(1)$

The model is approximated to,

$\left[\begin{array}{l}y_{1}(s) \\ y_{2}(s)\end{array}\right]=$

$\left[\begin{array}{cc}\frac{0.528 e^{(-0.6 s)}}{(2.2 s+1)} & \frac{0.081}{(1.89 s+1)} \\ \frac{\left(1.49 \times 10^{-4}\right) e^{(-1.5 s)}}{s} & -\frac{-7 \times 10^{-4} e^{(-2 s)}}{s}\end{array}\right]\left[\begin{array}{l}u_{1}(s) \\ u_{2}(s)\end{array}\right]$

$P_{\text {Headbox }}(S)=$

$\left[\begin{array}{cc}\frac{0.528 e^{(-0.6 s)}}{(2.2 s+1)} & \frac{0.081}{(1.89 s+1)} \\ \frac{\left(1.49 \times 10^{-4}\right) e^{(-1.5 s)}}{s} & -\frac{-7 \times 10^{-4} e^{(-2 s)}}{s}\end{array}\right]$

Where,

y1 - Pressure level in the head box

y2 - Stock level in the head box

$\mathrm{u} 1$ - Speed of the feed pump

$\mathrm{u} 2$ - air valve position.

The controlled variables in head box taken into consideration are pressure and stock level where the manipulated variables are speed and the air valve position. For the design of controller, a decoupled model is obtained [6]. A static decoupling method is used for the design purpose.

The decoupled models are:

$P_{11}(s)=\frac{-0.288 s^{2}+0.8825 s+0.5452}{1.247 s^{3}+5.365 s^{2}+4.39 s+1}$

$P_{22}(s)=\frac{5.421 s^{2}+1.693 s-7.229}{s\left(7500 s^{2}+17500 s+10000\right)}$

where $\mathrm{P}_{11}(\mathrm{~s})$ represents the pressure of head box and $\mathrm{P}_{22}(\mathrm{~s})$ represents the stock level of head box. The above models are taken into consideration for the design of PID controllers.

\section{DESIGN OF PID CONTROLLER}

PID controller is simple in configuration and its ease to design; it is widely used in most of the industrial processes. The tuning techniques brings out the massive performance of the PID controller. Proportionality constant (kp), integral constant (ki) and derivative constant (kd) are the three basic parameters of PID controller. The dynamic response of the system is improved by tuning of these parameters.

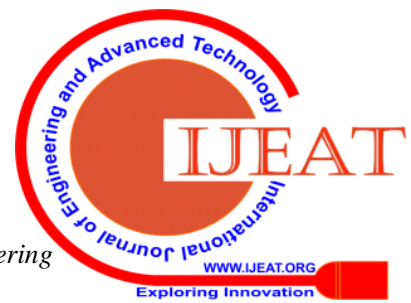


Elimination of steady state error and reduction in overshoot increases the stability and performance of the system [7].

$$
C(s)=U(s) / E(s)=k p+k i / s+k d s
$$

\section{Total Pressure of head box}

By the tuning of the controller for the pressure of head box eq. (4), the response is obtained by MATLAB Simulation as shown in figure 2 . The controller values are considered as $\mathrm{Kp}$ $=9.68, \mathrm{Ki}=12.05, \mathrm{kd}=1.86$.

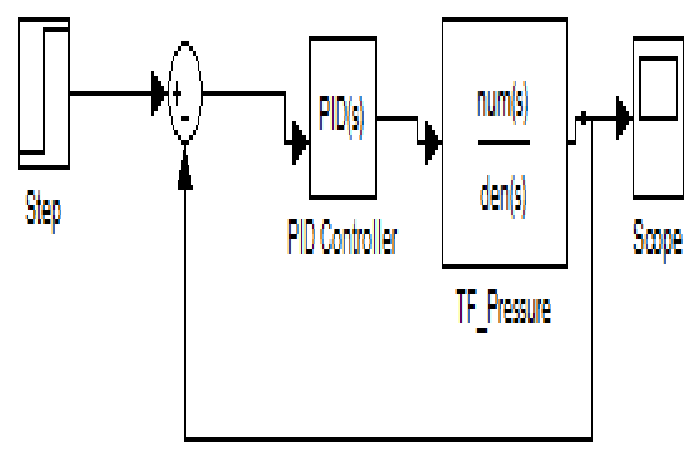

Fig. 2 Simulink SISO model of Head box Pressure

\section{Total Stock Level of head box}

By the tuning of the controller for the stock level of head box eq. (5), the response is obtained by MATLAB Simulation as shown in figure 4 . The controller values are considered as $\mathrm{Kp}=-836.35, \mathrm{Ki}=-264.32, \mathrm{kd}=-645.69$.

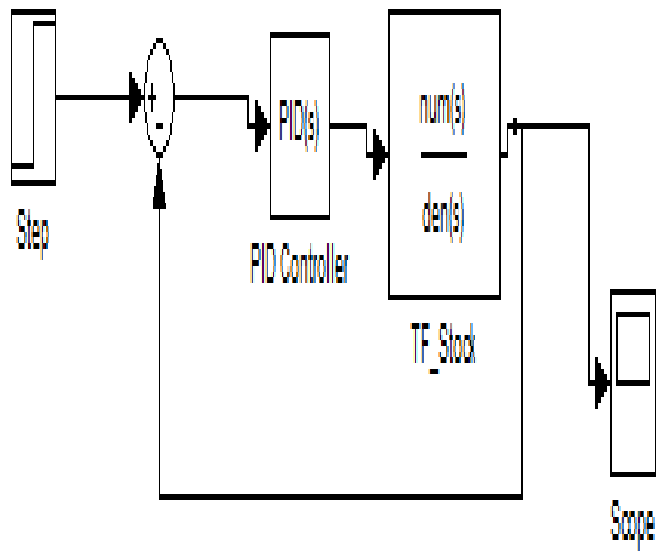

Fig. 3 Simulink SISO model of Head box Stock Level

\section{RESULTS AND DISCUSSION}

This section deliberates the analysis performance of controllers designed for the head box in paper machine. The step response analysis of the SISO models of Pressure and Head box are shown in figure 4 and 5. The response parameters are shown in Table 1 and 2.

The step response of Pressure in Head box of a paper machine is obtained as:

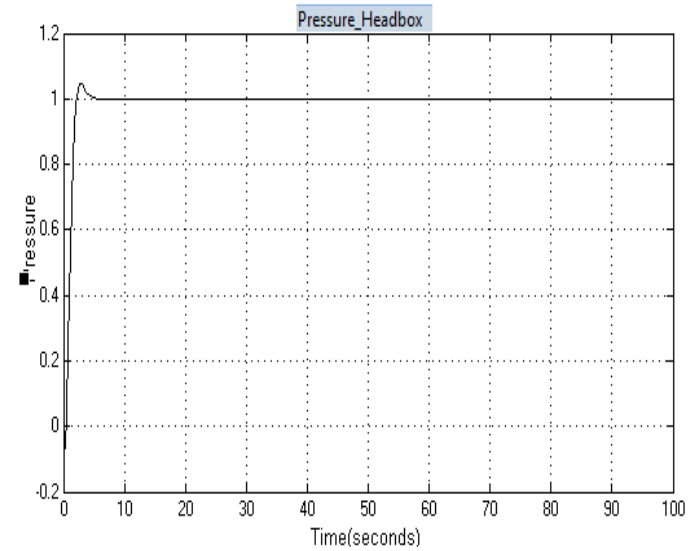

Fig. 4 Step response of Head box Pressure Table. 1 Response of Pressure

\begin{tabular}{|l|l|}
\hline Rise time (sec) & 1.17 \\
\hline Settling time (sec) & 3.83 \\
\hline Overshoot (\%) & 5.14 \\
\hline Peak & 1.05 \\
\hline
\end{tabular}

The step response of stock level in Head box of a paper machine is obtained as:

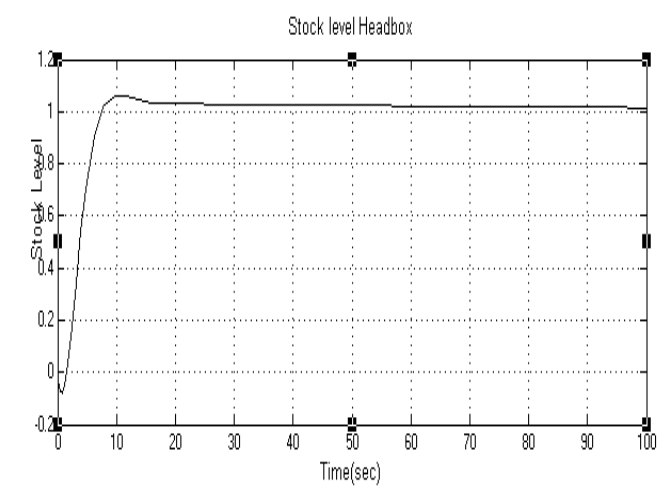

Fig. 5 Step response of Head box Stock Level Table. 2 Response of Stock Level

\begin{tabular}{|l|l|}
\hline Rise time $(\mathrm{sec})$ & 5.47 \\
\hline Settling time $(\mathrm{sec})$ & 69.3 \\
\hline Overshoot $(\%)$ & 6.07 \\
\hline Peak & 1.06 \\
\hline
\end{tabular}

\section{CONCLUSION}

From the results it is evident that the design of PID controller with step response analysis yields optimum results for SISO model.

The future scope of this work will be the comparison of performance on the basis of performance indices with different soft computing techniques.

\section{REFERENCES}

1. Ogunwusi.A.A, Ibrahim. H. D. (2014), Advances in pulp and paper technology and the implication for the paper industry in Nigeria, Industrial Engineering Letters, 4(10), 3-11.

2. Saini.P, Kumar.R.(2018), Brief review and mathematical modelling of air cushioned pressurized paper machine headbox, International Journal of Engineering and Technology (UAE), 7(3.4), 57-65. 
3. Paattilammi. J, Makila, P. M. (2000), Fragility and robustness: A case study on paper machine headbox control, IEEE Control Systems, 20(1), 13-22.

4. Whalley.R, Ebrahimi, M. (2002), Optimum control of a paper making machine headbox, Applied Mathematical Modelling, 26(6), 665-679.

5. Nissinen.A, Koivo. H. N,Huhtelin, T.(1996), Multivariable PI control of industrial paper machine headboxes, IFAC Proceedings Volumes, 29(1), 6686-6691.

6. Saini.P, Kumar. R, (2018), Stability analysis of paper machine headbox using a new PI(D) tuning technique, International Journal of Engineering and Technology, 7(2.6), 39-45.

7. Manikanthan, S.V., Padmapriya, T., An efficient cluster head selection and routing in mobile WSN, International Journal of Interactive Mobile Technologies, 2019.

8. Hussein I., Hussain A., Mkpojiogu E.O.C., Zaba Z.F. (2019). The User Centred Design (UCD) And User Experience Design (UXD) Practice In Industry: Performance Methods And Practice Constraints. International Journal of Recent Technology and Engineering. Vol 8. 2 Special Issue 2. Page 175-182

9. Santosh Kumar Das, Abhishek Kumar, Bappaditya Das and A.P.Burnwal (2013),On soft computing techniques in various areas, Rupak Bhattacharyya et al. (Eds) : ACER 2013, CS \& IT, pp. 59-68.

\section{AUTHORS PROFILE}

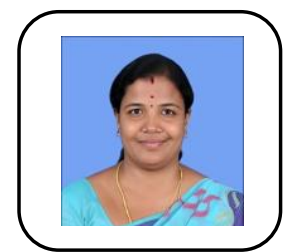

N. Divya is an Assistant Professor in the Department of Electrical and Electronics Engineering at Sri Ramakrishna Engineering College, Coimbatore. She is currently pursuing her part time Ph.D. in Anna University, Chennai. She has a teaching experience of more than 8 years. Her areas of interests are Control Systems and Microprocessors and Microcontrollers. She has published papers in Scopus indexed Journals and attended many International and National conferences.

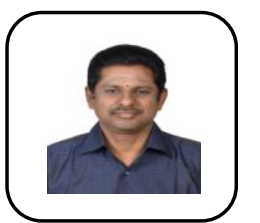

Dr. S. Manoharan took his B.E degree in Electrical and Electronics Engineering from Government College of Technology, Coimbatore in 1997, M.E degree in Electrical Machines from PSG College of Technology, Coimbatore in 2004 and Ph.D. in the area of Electrical Machines and drives from Anna University Chennai in July 2010. He has over 23 years of teaching experience. He is currently working as Professor and Head, Department of Electronics and Instrumentation Engineering in Karpagam College of Engineering, Coimbatore, Tamilnadu. He has published 100+ research papers in both National and international journals of repute and presented papers in National and International Conferences. . He has produced 5 Doctoral scholars. He is presently guiding 11 research scholars. He has published more than half a dozen-text books on Electrical and Electronics related fields. He is a life member of ISTE, SSI, C.Eng (I) and IEEE. 